УДК 316:376:339.1

Балук Н. Р., notika2002@ukr.net, ORCID ID: 0000-0001-7014-3152,

Researcher ID: E-9876-2019,

к.е.н., дои., дочент кафедри маркетингу, Львівський торговельно-економічний університет, м. Львів

Басій H. Ф.,

basij@ukr.net, ORCID ID: 0000-0001-7003-6007, Researcher ID: F-9024-2019, к.е.н., дои., доиент кафедри маркетингу, Львівський торговельно-економічний університет, м. Львів

\title{
ДОСЛІДЖЕННЯ СТАНУ ТА РІВНЯ КОМУНІКАЦІЙ НА РИНКУ ІНКЛЮЗИВНОГО НАВЧАННЯ
}

\begin{abstract}
Анотація. В статті проаналізовано статистичні показники чисельності осіб з особливими освітніми потребами в Украӥні та в розрізі окремих областей. Значна кількість дітей з ООП обумовлює необхідність запровадження та розвитку системи інклюзивної освіти на противагу їх сегрегаџії у спеціалізованих школахінтернатах. За допомогою контент-аналізу офіиійних сайтів виявлено недостатнє наповнення інтернетресурсів основних державних органів управління освітою та окремих громадських організацій. На основі аналізу результатів анкетного опитування вчителів загальноосвітніх закладів м. Львова та Львівської області виявлено низький рівень об'єктивної оцінки інклюзї та поверхову поінформованість про деталі й специфіку інклюзивного навчання. Досліджено, щзо загалом у шкільному середовищі м. Львова та Львівської області сформоване достатньо сприятливе середовище для імплементаџіï інклюзії. Окреслено основні комунікаційні зв'язки між учасниками прочесу інклюзї та не виявлено достатнього рівня комунікацій у жодному напрямі. Відсутні комунікаційні зв'язки між державними органами, громадськістю, батьками нормотипових дітей. Між дітьми з ООП та їхніми батьками та іншими дітьми інклюзивних класів та батьками існує мінімальний рівень комунікацій. Сформульовано переваги запровадження інклюзивного навчання для всіх учасників процесу інклюзї та суспільства загалом, ще дозволить всім членам суспільства безперешкодно отримувати всі необхідні суспільні послуги та гарантії, а також взаємно приносити посильну користь. Окреслено основні бар'єри комунікацій у середовищі інклюзії на різних рівнях: особистому рівні вчителів, рівні безпосереднього шкільного оточення дітей з ООП, загальношкільному та загальноосвітньому рівнях, а також на суспільному рівні. Більшість комунікативних перешкод зумовлені недостатністю інформації про особливості та переваги запровадження інклюзивного навчання. На основі аналізу сутності та природи перешкод сформульовано заходи щздо їх усунення.
\end{abstract}

Ключові слова: комунікації, бар’єри комунікації, рівень обізнаності, інклюзивне навчання, інклюзія, дитина з особливими освітніми потребами, переваги інклюзії.

Baluk N. R., notika2002@ukr.net, ORCID ID: 0000-0001-7014-3152,

Researcher ID: E-9876-2019,

Ph.D., Associate Professor, Associate Professor of the Department of Marketing, Lviv University of Trade and Economics, Lviv

Basij N. F.,

basij@ukr.net, ORCID ID: 0000-0001-7003-6007, Researcher ID: F-9024-2019, Ph.D., Associate Professor, Associate Professor of the Department of Marketing, Lviv University of Trade and Economics, Lviv

\section{RESEARCH ON THE STATE AND LEVEL OF COMMUNICATIONS IN THE INCLUSIVE EDUCATION MARKET}

\begin{abstract}
The article analyzes the statistical indicators of the number of people with special educational needs in Ukraine and in terms of individual regions. A significant number of children with special educational needs necessitate the introduction and development of an inclusive education system as opposed to their segregation in specialized boarding schools. With the help of content analysis of official sites, insufficient content of Internet resources of the main state education authorities and some public organizations was revealed. Based on the analysis of the results of the questionnaire survey of teachers of secondary schools in Lviv and Lviv region, a low level of objective assessment of inclusion and superficial awareness of the details and specifics of inclusive education was revealed. It is investigated
\end{abstract}


that in general the school environment of Lviv and Lviv region has formed a sufficiently favorable environment for the implementation of inclusion. The main communication links between the participants in the inclusion process are outlined and a sufficient level of communication in any direction is not identified. There are no communication links between government bodies, the public, and parents of normolipemic children. There is a minimum level of communication between children with special educational needs, their parents and other children and their parents in inclusive classes. The advantages of the introduction of inclusive education for all participants of inclusion process and society in general are formulated, which will allow all members of society to freely receive all necessary public services and guarantees, as well as bring mutual benefits. The main barriers to communication in the environment of inclusion at different levels are outlined: the personal level of teachers, the level of the immediate school environment of children with special educational needs, the whole-school and general education levels, as well as at the public level. Most communication barriers are due to a lack of information about the features and benefits of inclusive education inroduction. Based on the analysis of essence and nature of obstacles, measures to eliminate them are formulated.

Key words: communications, communication barriers, level of awareness, inclusive education, inclusion, child with special educational needs, benefits of inclusion.

$$
\begin{aligned}
& \text { JEL classification: I21, I28, I29, I31, J24 } \\
& \text { DOI: https://doi.org/10.36477/2522-1205-2020-59-04 }
\end{aligned}
$$

Постановка проблеми. Українське суспільство перебуває на етапі реформування усіх сфер життєдіяльності - економічної, політичної, соціальної, культурної, освітньої, медичної тощо. Одним із стратегічних напрямів сучасної української освіти визначено важливість соціалізації та інклюзії для осіб з особливими освітніми потребами (ООП).

Одним із основоположних документів ефективного запровадження інклюзії в світі стала Саламанська декларація "Про принципи, політику i практичну діяльність в сфері навчання осіб з особливими потребами", прийнята на засіданні ЮНЕСКО в 1994 р., згідно з якою всі діти мають право навчатися у звичайній школі незалежно від їхнього фізичного та інтелектуального розвитку, соціального статусу, захворювання, емоційного стану, знання мов, раси, країни походження, статі тощо [1]. В багатьох країнах перехід від сегрегації до інтеграції й інклюзії в освіті відбувався за різними сценаріями та алгоритмами, що засвідчило не лише про непростий та тривалий механізм впровадження інклюзії, але й про неможливість створення універсальної моделі навчання. Проте досвід більшості країн, які запровадили інклюзію, свідчить про успішність використання такої форми навчання - в суспільстві повною мірою виконується захист прав людини, адже дозволяє кожній дитині реалізувати свої права i можливості, кожній особі з особливими потребами бути повноправним членом соціуму.

У 2009 р. Україна ратифікувала Конвенцію про права осіб з інвалідністю та взяла на себе низку зобов'язань, у тому числі щодо забезпечення їх права на освіту. 3 вересня 2017 р. в Україні, згідно з прийнятими змінами до Закону України "Про освіту", особи 3 ООП отримали можливості доступу до освітніх послуг в усіх навчальних закладах незалежно від “встановлення інвалідності” [2]. Саме у цей час в українських школах почали працювати інклюзивні класи, в кожному 3 яких можуть навчатися не більше трьох осіб з ООП, розроблятися навчальні індивідуальні плани, проводитися уроки, стикатися 3 першими успіхами та труднощами.
Парадокс менталітету української нації - у двозначному ставленні до багатьох питань, важливих для функціонування соціуму. За результатами дослідження, проведеного ЮНІСЕФ у 2015 р., 96 \% українців згідні 3 твердженням, що діти 3 інвалідністю повинні мати такі ж права й можливості, як і нормотипові діти, проте лише 13\% респондентів готові сприймати дітей з особливими потребами як друзів і рівноправних громадян [3].

Очевидно, що українське суспільство неповною мірою готове до запровадження інклюзивного навчання через існуючі психологічні (стереотипи сприйняття, насаджена в радянські часи практика “неіснування” осіб з інвалідністю, нерівноправність верств населення тощо) та матеріально-технічні бар'єри (відсутність пандусів у більшості житлових будинків, закладів харчування, публічних установ, відсутність спеціально облаштованих туалетних кімнат, відсутність світлових та звукових сигналів, надписів з використанням шрифту Брайля тощо).

Аналіз останніх досліджень і публікацій. Наявний механізм запровадження інклюзії в українських реаліях характеризується наявністю багатьох перешкод в комунікаційному процесі між іiі основними учасниками. Як свідчить аналіз 3MI, існує цілий ряд невирішених питань і серед педагогів та фахівців, і серед батьків дітей з ООП, і серед батьків нормотипових дітей, і в соціумі загалом $[4 ; 5 ; 6$; $7 ; 8]$. Це стосується і відсутності довіри між учасниками, і відсутності досвіду, і відсутності ефективних комунікацій, в тому числі з боку державних органів влади. В офіційних джерелах зазначається, що впровадження інклюзивного навчання в українських реаліях стримується необхідністю вирішення завдань, пов'язаних із нормативно-правовим, організаційно-фінансовим, кадровим, науково- та навчально-методичним забезпеченням навчання та виховання з ООП $[9 ; 10]$.

Відтак для визначення рівня наявних комунікацій при запровадженні інклюзивного навчання в Україні необхідно з'ясувати, які саме фактори мають найбільший вплив на цей процес, які 
можливі шляхи вирішення нейтралізації негативного впливу в комунікаціях між всіма учасниками в інклюзивному середовищі.

Постановка завдання. Основною метою нашого дослідження є визначити рівень комунікацій на ринку інклюзивного навчання у загальноосвітніх школах України на прикладі м. Львова і Львівської області.

Виклад основного матеріалу дослідження. У будь-якому суспільстві серед усіх верств населення є особи $з$ інвалідністю. В Україні за останні роки частка таких осіб зросла $33 \%$ до $6 \%$ в загальній чисельності населення [11]. В розрізі областей України аналіз цього показника станом на 2017 р. засвідчив, що найбільша частка осіб з інвалідністю у Львівській області - 7,7\%, значно менша частка у Дніпропетровській та Харківській областях відповідно 6,7 і 6,4 \%, а найнижчий показник - у Луганській, Херсонській і Чернівецькій областях (по 2 \%). Частка дітей з інвалідністю до 18 р. у загальній чисельності дитячого населення 0-17 р. в Україні станом на 2017 р. найвища у Дніпропетровській, Львівській та Харківській областях, найнижча - у Луганській, Сумській, Кіровоградській, Херсонській і Чернівецькій областях.

Інвалідність - складне соціальне явище, щодо якого у держави та іiі громадян має бути усталене ставлення та підтримка. Значна кількість дітей 3 інвалідністю в Україні потребує створення певних умов, за яких вони зможуть нарівні з іншими членами суспільства отримувати рівні можливості для реалізації своїх прав. Однією з таких можливостей $€$ інклюзивна освіта.

Інклюзивне навчання не $\epsilon$ вибором окремої школи чи групи шкіл, це вектор життя країни. Метою інклюзивної освіти $є$ виховати повноправних членів суспільства шляхом залучення всіх учасників навчального процесу до загальношкільної діяльності. При цьому, коли мова йде про дитину 3 ООП, слід зважати, що іiі повносправність може бути умовною, але не повинна бути константою, має залежати від обставин, у яких перебуває дитина, від іiі можливостей та бажання стати учасником тієї чи іншої події [17]. Для максимального використання можливостей інклюзії необхідна повна поінформованість всіх зацікавлених осіб та організацій [18].

Досвід застосування інклюзивного навчання для дітей з ООП у світовій практиці засвідчив переваги такого підходу і став основою для його запровадження в Україні. У вітчизняній системі освіти інклюзивний підхід до навчання перебуває на етапі становлення.

За даними Міністерства освіти і науки України, кількість дітей, охоплених інклюзивним навчанням, за останні роки має тенденцію до зростання (табл. 1). У 2016-2017 н.р. найбільшу кількість дітей з ООП залучили до інклюзії у м. Києві,
Волинській і Полтавській областях, найменшу - в Миколаївській і Харківській областях. При цьому в школах Миколаївської області, єдиної в Україні, за останній навчальний рік чисельність дітей, охоплених інклюзією, зменшилась у порівнянні $з$ попереднім навчальним роком на $18 \%$.

Аналіз офіційних даних свідчить, що рівень охоплення дітей з ООП інклюзією в Україні загалом зростає, проте характеризується недостатнім рівнем. У 2016-2017 н.р. до інклюзивного навчання було залучено 2,7\% усіх дітей 3 інвалідністю до 18 р. У промислово розвинених країнах цей показник наближається до 95\%.

До основних учасників інклюзивного процесу належать: діти з ООП та їхні батьки, педагоги, адміністрація школи, профільні фахівці, нормотипові діти та їхні батьки, державні органи влади, громадські організації, широка громадськість.

Діти з ООП на сьогодні в українських реаліях мають можливість навчатися за такими формами: в спеціальних школах та освітніх навчальнореабілітаційних центрах, в спеціальних класах загальноосвітніх шкіл, в звичайних класах загальноосвітніх шкіл, в інклюзивних класах загальноосвітніх шкіл та за індивідуальною формою навчання. Найбільш прийнятне 3 точки зору дитиноцентристської педагогічної парадигми - інклюзивне навчання дітей з ООП.

Не всі учасники інклюзивного процесу розуміють власне сутність інклюзії та механізм іiі запровадження. Це обумовлюється відсутністю повної інформації з боку державних органів влади як ключового комунікатора в інклюзивному процесі.

Аналіз вибраних ключових українських інтернет-ресурсів засвідчив, що більшість 3 них містять дані про нормативно-правові акти (закони, постанови КМУ, накази МОН), методичні матеріали щодо інклюзії, інформацію новинного характеру (про конкретні події чи проведені заходи). Інформація на вибраних ключових українських інтернетресурсах орієнтована лише на батьків дітей з ООП і педагогів. При цьому представлені матеріали загального характеру, без конкретної спрямованості на вирішення проблем. Для решти учасників інклюзивного процесу (зокрема, для нормотипових дітей та їхніх батьків, широкої громадськості) інформація про інклюзію представлена в офіційних каналах комунікації, які зазвичай малоефективні саме для цих цільових аудиторій. Не менш важливою цільовою аудиторією і водночас найпотужнішим комунікатором в інклюзії є громадські організації. На сайтах окремих організацій наявна найбільш повна і вичерпна інформація про інклюзивну освіту. 
Вісник Львівського торговельно-економічного університету. Економічні науки. № 59, 2020

Таблиияя 1

Динаміка показників запровадження інклюзії в Україні у 2014-2017 н.р.

\begin{tabular}{|c|c|c|c|c|c|}
\hline \multirow[b]{2}{*}{ Назва області України } & \multicolumn{3}{|c|}{ Кількість дітей, осіб } & \multicolumn{2}{|c|}{ Темп зростання з року в рік, \% } \\
\hline & $\begin{array}{c}\text { 2014-2015 } \\
\text { H.p. }\end{array}$ & $\begin{array}{c}\text { 2015-2016 } \\
\text { H.p. }\end{array}$ & $\begin{array}{c}2016-2017 \\
\text { H.p. }\end{array}$ & $\begin{array}{c}2015-2016 / \\
2014-2015 \text { н.p. }\end{array}$ & $\begin{array}{c}\text { 2016-2017/ } \\
\text { 2015-2016 н.p. }\end{array}$ \\
\hline Вінницька & 31 & 42 & 113 & 135,5 & 269,0 \\
\hline Волинська & 145 & 156 & 268 & 107,6 & 171,8 \\
\hline Дніпропетровська & 152 & 168 & 237 & 110,5 & 141,1 \\
\hline Донецька & 0 & 81 & 108 & 0,0 & 133,3 \\
\hline Житомирська & 83 & 158 & 260 & 190,4 & 164,6 \\
\hline Закарпатська & 74 & 108 & 151 & 145,9 & 139,8 \\
\hline Запорізька & 57 & 66 & 147 & 115,8 & 222,7 \\
\hline Івано-Франківська & 5 & 13 & 54 & 260,0 & 415,4 \\
\hline Київська & 232 & 287 & 443 & 123,7 & 154,4 \\
\hline Кіровоградська & 58 & 99 & 188 & 170,7 & 189,9 \\
\hline Луганська & 9 & 12 & 35 & 133,3 & 291,7 \\
\hline Львівська & 97 & 62 & 149 & 63,9 & 240,3 \\
\hline Миколаївська & 33 & 39 & 32 & 118,2 & 82,1 \\
\hline Одеська & 92 & 99 & 118 & 107,6 & 119,2 \\
\hline Полтавська & 176 & 200 & 266 & 113,6 & 133,0 \\
\hline Рівненська & 86 & 109 & 197 & 126,7 & 180,7 \\
\hline Сумська & 37 & 42 & 72 & 113,5 & 171,4 \\
\hline Тернопільська & 44 & 31 & 68 & 70,5 & 219,4 \\
\hline Харківська & 24 & 24 & 33 & 100,0 & 137,5 \\
\hline Херсонська & 116 & 110 & 154 & 94,8 & 140,0 \\
\hline Хмельницька & 212 & 209 & 227 & 98,6 & 108,6 \\
\hline Черкаська & 56 & 54 & 135 & 96,4 & 250,0 \\
\hline Чернівецька & 8 & 130 & 169 & 1625,0 & 130,0 \\
\hline Чернігівська & 56 & 76 & 112 & 135,7 & 147,4 \\
\hline м. Київ & 282 & 345 & 444 & 122,3 & 128,7 \\
\hline Усього & 2165 & 2720 & 4180 & 125,6 & 153,7 \\
\hline
\end{tabular}

Розраховано на основі джерела 19

Одним із основних учасників процесу інклюзії з боку школи виступає вчитель інклюзивного класу. Саме від його фаховості та вміння організувати навчальний процес залежить результативність інклюзивного навчання. Ця результативність полягає не лише в отриманні знань, навичок, вмінь, компетентностей, але й залученні кожної дитини в інклюзивному класі в усі аспекти шкільної освіти 3 урахуванням її можливостей і бажань. Проте не все залежить лише від учителя. Адже педагогічні ВН3 не готують вчителів для роботи в інклюзивних клаcax. Часто педагоги не володіють необхідною мотивацією, а якщо вона є, то кваліфікація може бути недостатньою, відсутня інформація про основні ресурси інклюзивного навчання (де їх отримати, як використовувати тощо).

Вітчизняні фахівці перебувають на етапі професійної трансформації - намагаються здобувати нові знання, змінювати особисті та педагогічні установки, здобувають новий досвід та результати.

Переваги інклюзивного навчання очевидні: інтеграція та адаптація дітей з ООП поряд 3 вихованням толерантності у дітей без ООП. Очевидно, що для практичного втілення цієї ініціативи існують труднощі матеріальні та ресурсні. Проте постає головне питання: чи готові, власне, педагоги до створення інклюзивних класів? Чи поінформовані вони про інклюзивну освіту та чи зможуть правильно організувати освітній процес і якісно навчати дітей?

Для забезпечення відповідного позитивного ставлення до якогось явища необхідний відповідний рівень його усвідомлення та розуміння. Як показали результати опитування, 94,1\% вчителів Львівської області та 95,0\% вчителів м. Львова зазначили: вони знають, що таке інклюзивна освіта. Проте коректне визначення інклюзивної освіти обрали лише 74,7\% вчителів по області та 72,4\% по Львову. Показник дещо нижчий, проте достатньо високий. Розбіжність між показниками свідчить про недостатність комунікацій, що спрямовуються на одного з важливих учасників процесу інклюзії педагогів.

Показово, що інформацію про інклюзивну освіту педагоги отримують переважно 3 мережі Інтернет: зокрема, різними інтернет-ресурсами користуються $53,1 \%$ респондентів, веб-сторінками відділів освіти - 21,0\%. Дещо менша частка вчителів отримують інформацію про інклюзію за ЗМІ (телебачення, радіо, газети, журнали) - 40,7\%. Достатньо вагомою $є$ частка вчителів, які отримали відповідну інформацію на курсах підвищення 
кваліфікації $(29,2 \%)$ та спеціальних тренінгах чи семінарах $(10,7 \%)$, на педрадах або методоб'єднаннях (13,6\%).

Попри високі показники поінформованості педагогів 3 поняттям інклюзіï, аналіз відповідей на інші запитання засвідчив недостатню ефективність комунікацій стосовно даного питання. Лише 7,8\% опитаних вчителів Львівської області та 11,3\% вчителів Львова вказали правильну відповідь про умови навчання дитини з ООП в інклюзивному класі за ініціативи батьків. Більшість вчителів вважають такою умовою висновок педагога та практичного психолога після спостереження за дитиною протягом місяця (83,6\% по області та 78,9\% по Львову).

Про те, де варто шукати навчальні програми для дітей з ООП, зовсім не знають 10,4\% вчителів Львова і 6,5\% опитаних по області. Достатньо значна частка вчителів володіють хоча б якоюсь коректною інформацією (87,8\% -Львівська область та 93,6\% - Львів), але жоден опитаний не вказав усі можливі ресурси, де можна знайти програму навчання для дітей з ООП - сайт МОН України; навчально-методичний центр освіти; звернувшись за психолого-медико-педагогічною консультацією.

Про недостатність поінформованості вчителів свідчить також те, що, хоча обізнаність про те, за якою програмою повинні навчатися діти 3 ООП, задекларували понад $70 \%$ опитаних $(72,2 \%$ Львівська область, 70,3\% - Львів), однак правильно конкретизувати свою відповідь змогли лише 33,2\% вчителів Львівської області та 42,6\% вчителів Львова.

Важливою, на нашу думку, також є поінформованість педагогів про те, хто саме повинен укладати індивідуальну програму для дітей з ООП. Усіх учасників цього процесу зазначили по Львову $20,0 \%$ опитаних, а по Львівській області ще менше - 8,2\% опитаних. Скільки дітей може навчатися в інклюзивному класі (до 20 учнів загалом) знають 15,8 та 28,9\% педагогів Львівської області та м. Львова відповідно. Коректною інформацією про оцінювання дітей 3 ООП володіють лише відповідно 22,2\% та 25,0\% опитаних.
Важливою, з нашого погляду, є наявність у вчителів певного досвіду роботи в інклюзивних класах або з дітьми з ООП. Більшість вчителів зазначили, що мають такий досвід спілкування (80,4\% опитаних), а 46,3\% навчали дітей 3 ООП індивідуально, 19,6\% - в інклюзивному класі, 3,3\% на засадах волонтерства, $0,9 \%$ - в звичайному класі.

Значна частка респондентів (68,6\% - Львівська область, 67,2\% - Львів) виражають готовність працювати 3 дітьми з ООП (зокрема, в інклюзивному класі). Проте вони зазначають, що бракує підготовки: курсів, тренінгів, семінарів, які б дали можливість підвищити кваліфікацію саме в сфері інклюзії, i, як наслідок, - недостатність спеціальних знань та навичок.

Результати дослідження ще раз підтверджують необхідність запровадження більш ефективних засобів комунікацій з вчителями - однією 3 основних цільових аудиторій та одними з основних учасників процесу інклюзії.

Такі комунікації повинні перш за все виражатись у методичній та консультативній допомозі вчителям для роботи в інклюзивному класі. Власне таку методичну допомогу отримували 52,2\% вчителів Львівської області та 64,3\% вчителів Львова. Консультативна допомога надавалась 76,2\% та $86,7 \%$ вчителів відповідно. Джерелами як методичної, так і консультативної допомоги здебільшого виступали навчально-методичні центри освіти та досвідчені колеги зі школи (табл. 2).

Отримані результати опитування засвідчили недостатність консультативної допомоги вчителям інклюзивних класів 3 боку навчально-методичних центрів освіти. Проте саме ці установи повинні бути основним джерелом необхідної інформації та консультацій у сфері інклюзії.

Однією з цілей запровадження інклюзії $є$ формування толерантного ставлення до дітей з ООП 3 боку шкільного оточення, забезпечення комфортних умов отримання освітніх послуг, попередження та недопущення упередженого ставлення чи агресії стосовно таких учнів з боку інших дітей чи дорослих.

Таблиця 2

Агенти надання методичної та консультативної допомоги вчителям щодо організації інклюзивного процесу

\begin{tabular}{|c|c|c|c|c|}
\hline \multirow{2}{*}{ Агенти } & \multicolumn{2}{|c|}{$\begin{array}{c}\text { Частка вчителів, що отримували } \\
\text { методичну допомогу, \% }\end{array}$} & \multicolumn{2}{|c|}{$\begin{array}{c}\text { Частка вчителів, що отримували } \\
\text { консультативну допомогу, \% }\end{array}$} \\
\hline & $\begin{array}{l}\text { Львівська } \\
\text { область }\end{array}$ & Львів & $\begin{array}{l}\text { Львівська } \\
\text { область }\end{array}$ & Львів \\
\hline $\begin{array}{l}\text { Навчально-методичні центри } \\
\text { освіти }\end{array}$ & 52,2 & 60,0 & 21,9 & 46,2 \\
\hline $\begin{array}{l}\text { Психолого-медико-педагогічні } \\
\text { консультації }\end{array}$ & 47,8 & 60,0 & 34,4 & 46,2 \\
\hline Досвідчені колеги з їхньої школи & 52,2 & 60,0 & 75,0 & 69,2 \\
\hline Досвідчені колеги з інших шкіл & 30,4 & 40,0 & 21,9 & 30,8 \\
\hline
\end{tabular}


Основними засобами комунікацій, що можуть застосовуватися щодо цієї цільової аудиторії (шкільне оточення дитини з ООП) можуть бути тематичні уроки, ознайомчі лекції, розмови та бесіди $з$ учнями інклюзивних класів та їхніми батьками. Необхідність таких заходів відзначили 82,8\% вчителів Львівської області та 87,5\% вчителів Львова. Педагоги мотивують це користю для звичайних учнів інклюзивних класів, які в результаті навчаться спілкуватися 3 дітьми 3 ООП, будуть належно сприймати їх, навчаться милосердя та толерантного ставлення до всіх людей, незалежно від їхніх особливостей.

90,6\% вчителів Львівської області та 73,3\% вчителів Львова проводили спеціальні заходи 3 учнями інклюзивного класу про однокласників 3 ООП і загалом про людей $з$ інвалідністю. Якщо ж такі заходи не проводилися, то вчителі здебільшого пояснюють це відсутністю потреби (оскільки є розуміння з боку дітей) або тим, що батьки чи класний керівник вже проводили подібні бесіди. Певна частка вчителів (достатньо незначна) вважає проведення подібних заходів недоцільним через дві основні причини: зайве виокремлення дітей з ООП може бути шкідливим; інклюзія є складною темою для сприйняття учнями.

Щодо формату таких бесід, то це здебільшого розмови під час виховних годин $(40,0 \%$ - Львів, $29,6 \%$ - Львівська область), ознайомча лекція в позаурочний час (відповідно $30,0 \%$ та $25,9 \%$ ).
Індивідуальні бесіди та ознайомчі лекції під час уроків менш популярні (рис. 1).

За оцінками респондентів, загальне ставлення до дітей з ООП є позитивним:

- однокласники у переважній більшості схильні всіляко їм допомагати $(97,6 \%$ - Львівська область, 93,3\% - Львів);

- лише 2,4\% вчителів у Львівській області та 6,7\% по Львову спостерігали відсутність взаємодії та ігнорування учнів з ООП іншими учнями інклюзивного класу;

- 78,0\% батьків інших дітей школярів Львівської області та 85,7\% Львова позитивно реагували щодо інформації про навчання їхньої дитини в інклюзивному класі;

- жоден респондент не зазначив прикладів ворожого чи агресивного ставлення до дітей з ООП.

Основними проблемами, як свідчать результати опитування, є недостатня поширеність та результативність комунікативної і просвітницької діяльності саме з батьками дітей інклюзивних класів. Це вимагає проведення роз'яснювальних бесід, а також проведення регіональних та загальнонаціональної широкомасштабної кампанії зі зв'язків 3 громадськістю щодо пропаганди інклюзії. Така кампанія повинна включати комплекс заходів соціальної реклами, пропаганди толерантного ставлення до людей з особливими потребами, проведення публічних заходів.

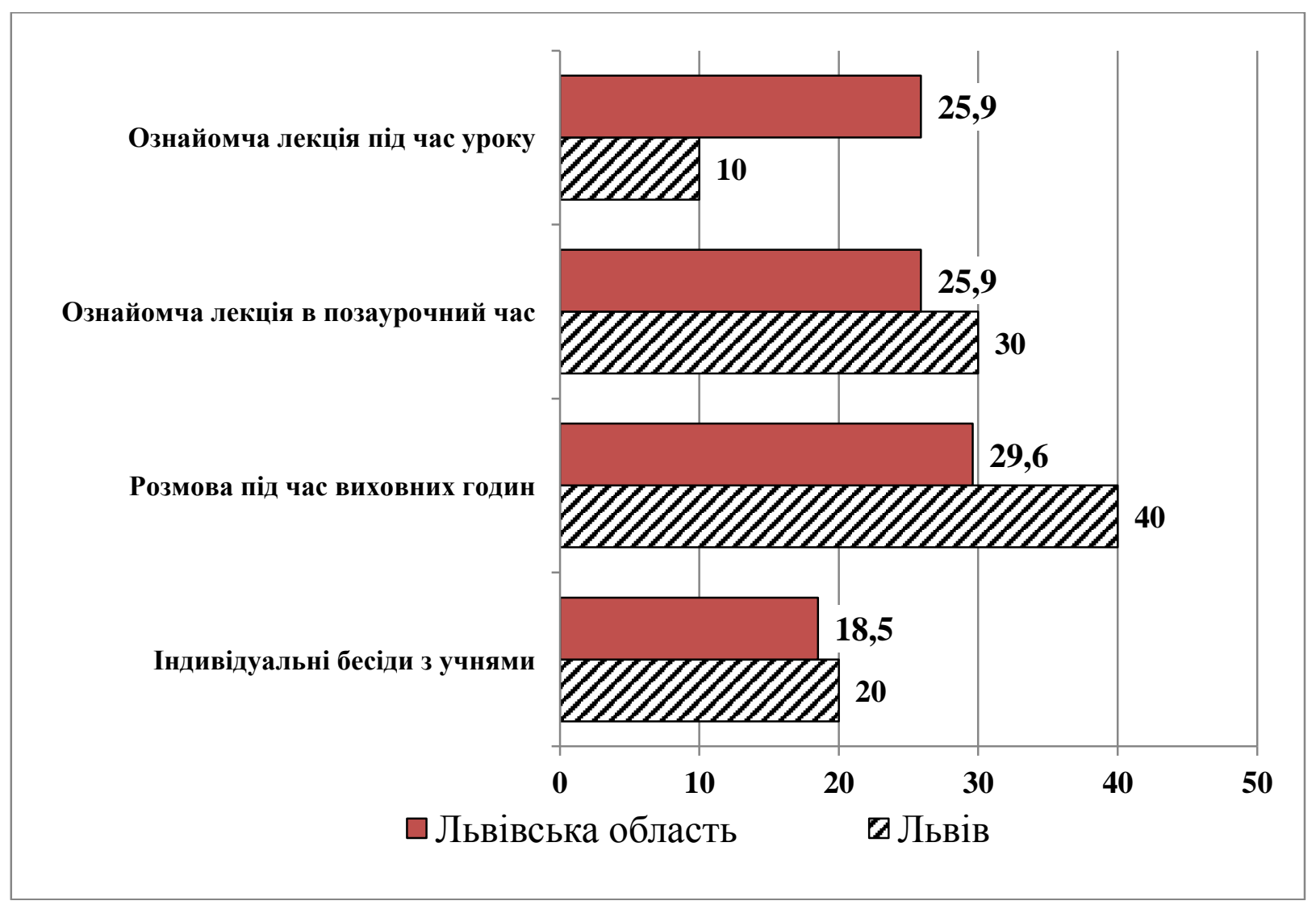

Рис. 1. Формат проведення бесід з учнями інклюзивних класів, \% 


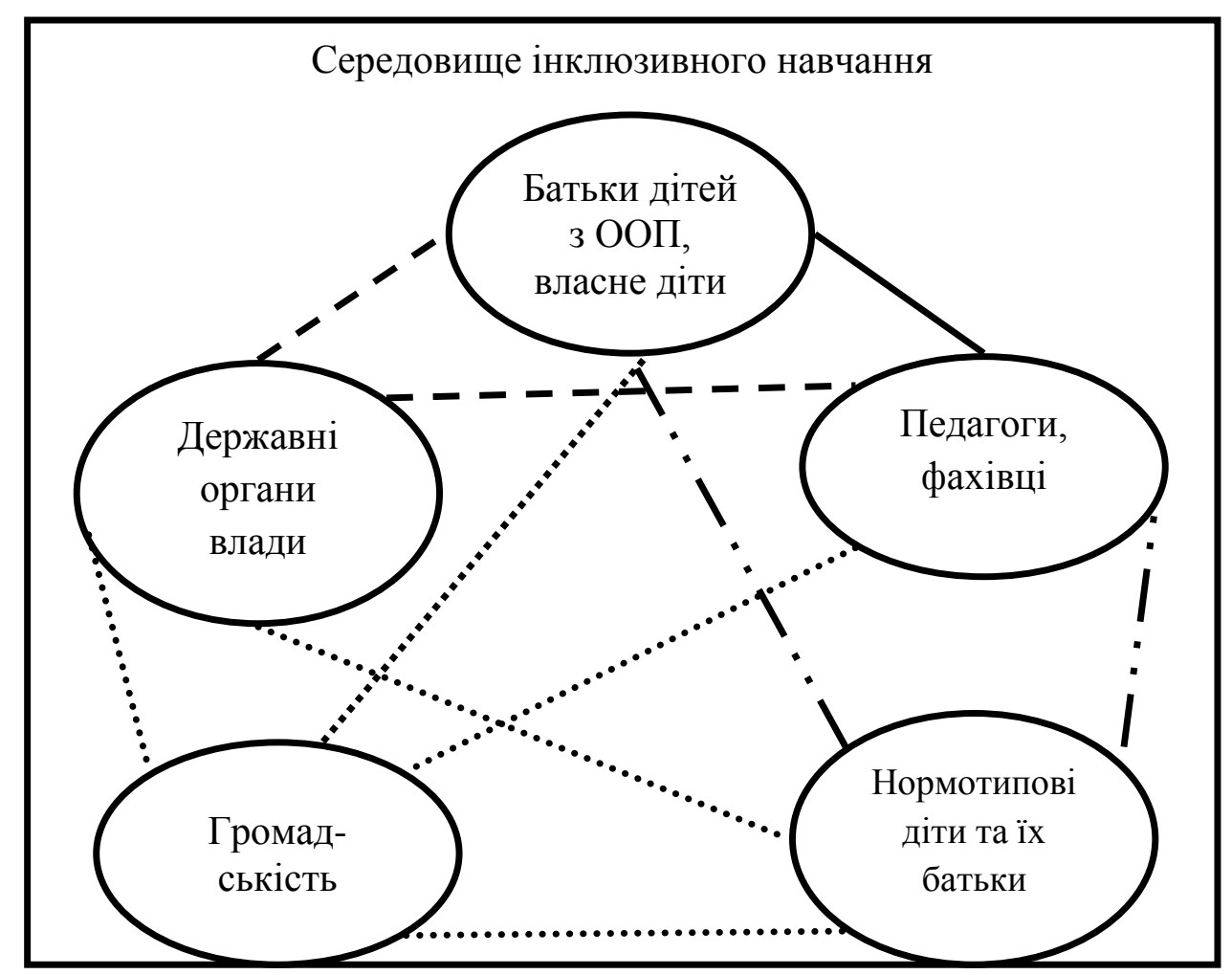

Рис. 2. Основні комунікаційні зв'язки між учасниками в середовищі інклюзивного навчання

Умовні позначення:

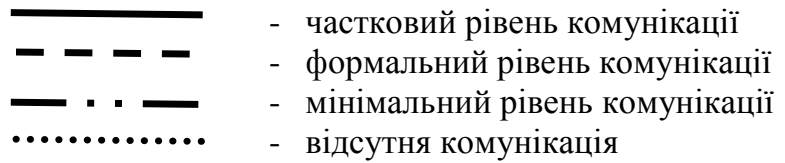

Ефективність інклюзивного процесу повною мірою залежить від наявності та якості комунікацій між основними учасниками. На сьогодні батьки дітей з ООП є найбільш зацікавленою стороною в комунікації, проте яка водночас володіє і найбільшою недовірою до державних органів влади та інших учасників інклюзивного процесу. Оцінюючи комунікації в сфері інклюзії, можна констатувати відсутність достатнього їх рівня між всіма учасниками (рис. 2). Частково комунікація налагоджена між батьками дітей з ООП і педагогами та профільними фахівцями. При цьому слід зазначити, що значна частка педагогів не сприймають батьків як співпартнерів і власне фахівців у розробці індивідуальної програми навчання своєї дитини.

Державні органи влади підтримують комунікації на формальному рівні лише 3 двома цільовими аудиторіями - педагогами, фахівцями та батьками дітей 3 ООП. 3 іншими учасниками комунікації відсутні. Проте забезпечення комплексного підходу до ефективності впровадження інклюзії неможливе без достатнього інформування і залучення до цього процесу 3 боку держави батьків нормотипових дітей, власне їхніх дітей та широкої громадськості.

Мінімальний рівень комунікації в середовищі інклюзивного навчання характерний між педагогами, фахівцями і батьками нормотипових дітей, а також широкою громадськістю. Такий стан речей не сприяє ефективності інклюзії, оскільки власне педагогічний склад шкіл повинен виступати транслятором ставлення до дітей з ООП і їх залучення до шкільної освіти. Тут вкотре важливо наголосити на необхідності підвищення професійної компетентності усіх фахівців, залучених до процесу інклюзивного навчання.

Аналіз комунікаційних зв'язків між всіма учасниками інклюзивного процесу виявив відсутність достатнього рівня комунікацій. Варто відзначити важливість роботи громадських організацій у процесі запровадження інклюзії. Вони є ініціаторами більшості змін та нововведень у середовищі інклюзії.

Процес комукації між основними учасниками в середовищі інклюзивного навчання, як і будь-якої іншої комунікації, пов'язаний із наявністю перешкод. Ці перешкоди можуть мати різну природу походження, різний вплив (від спотворення інформації аж до повного блокування процесу комунікації) та різні прояви і наслідки.

Основні комунікативні перешкоди у сфері інклюзивного навчання, на нашу думку, пов'язані 3 особистими бар'єрами педагогів, фахівців, внутрішньошкільними бар'єрами, перешкодами безпосереднього шкільного оточення (нормотипові діти та їхні батьки), загальноосвітніми і суспільними бар'єрами (табл. 3). 
Вісник Львівського торговельно-економічного університету. Економічні науки. № 59, 2020

Основні бар'єри комунікацій у сфері інклюзії та засоби їх усунення

Табличя 3

\begin{tabular}{|c|c|c|}
\hline Бар'єри & Мета комунікації & $\begin{array}{c}\text { Заходи та засоби комунікацій для } \\
\text { подолання наявних і латентних } \\
\text { бар'єрів }\end{array}$ \\
\hline $\begin{array}{l}\text { Особисті бар'єри вчителів } \\
\text { - вважають, що й так все достатньо } \\
\text { добре; } \\
\text { - думають, що не мають, або дійсно не } \\
\text { мають достатніх знань і навичок; } \\
\text { - побоюються, що їхня некомпетент- } \\
\text { ність стане очевидною для адміністрації } \\
\text { школи або колег; } \\
\text { - побоюються, що робота потребувати- } \\
\text { ме надто багато часу чи інших ресурсів; } \\
\text { - не впевнені, що буде потрібна } \\
\text { підтримка та ресурсне забезпечення } 3 \\
\text { боку адміністрації та державних органів }\end{array}$ & $\begin{array}{l}\text { - Професійна трансформація та пере- } \\
\text { осмислення вчителями власних педа- } \\
\text { гогічних компетентностей; } \\
\text { - подолання особистих бар'єрів за допо- } \\
\text { могою підвищення власного професійно- } \\
\text { го рівня; } \\
\text { - усвідомлення того, що бути вчителем } \\
\text { означає самому вчитися протягом усього } \\
\text { життя. }\end{array}$ & \multirow{5}{*}{ 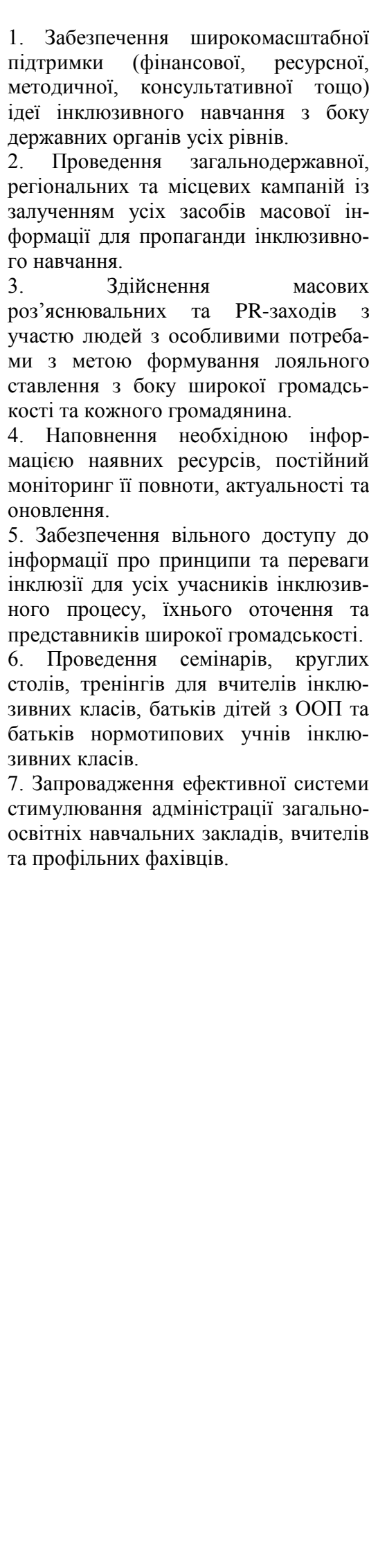 } \\
\hline $\begin{array}{l}\text { Внутрішньошкільні бар'єри } \\
\text { - порівняно автономне середовище } \\
\text { школи не сприяє співпраці вчителів, } \\
\text { командному плануванню, спільному } \\
\text { вирішенню проблем; } \\
\text { - неприйнятя, вороже ставлення до } \\
\text { нових ідей, які надходять “зверху”; } \\
\text { - усталеність форми функціонування } \\
\text { школи та організації шкільних занять; } \\
\text { - н непристосованість більшості } \\
\text { приміщень загальноосвітніх навчальних } \\
\text { закладів для навчання дітей з ООП } \\
\text { (відсутність пандусів, спеціально } \\
\text { обладнаних туалетних кімнат, шкільно- } \\
\text { го приладдя, підручників та методично- } \\
\text { го забезпечення тощо). }\end{array}$ & $\begin{array}{l}\text { - Стимулювання обміну досвідом між } \\
\text { вчителями; } \\
\text { - збільшення мотивації для впровадження } \\
\text { інклюзії; } \\
\text { - подолання інертності в шкільному сере- } \\
\text { довищі; } \\
\text { - усунення фізичних перешкод та фор- } \\
\text { мування доступності навчальних закладів } \\
\text { для всіх дітей за допомогою вдоскон- } \\
\text { лення матеріально-технічного забезпе- } \\
\text { чення. }\end{array}$ & \\
\hline $\begin{array}{l}\text { Бар'єри безпосереднього шкільного } \\
\text { оточення (нормотипові діти та їхні } \\
\text { батьки) } \\
\text { - несприйняття інклюзії загалом; } \\
\text { - вимога ізолювати дітей з ООП; } \\
\text { - страх перед дітьми з ООП; } \\
\text { - ігнорування дітей з ООП; } \\
\text { - нетолерантне, агресивне ставлення до } \\
\text { дітей з ООП. }\end{array}$ & $\begin{array}{l}\text { - Формування розуміння унікальності } \\
\text { кожної особистості незалежно від її особ- } \\
\text { ливостей; } \\
\text { - створення комфортного та сприятливого } \\
\text { шкільного середовища для дітей з ООП } \\
\text { та нормотипових дітей; } \\
\text { - забезпечення взаємного сприйняття, } \\
\text { поваги та позитивного ставлення один до } \\
\text { одного усіма учнями інклюзивного класу. }\end{array}$ & \\
\hline $\begin{array}{l}\text { Загальноосвітні бар'єри } \\
\text { - недостатнє фінансування освіти та } \\
\text { інклюзивної освіти зокрема; } \\
\text { - низький рівень забезпечення спеціаль- } \\
\text { ної та педагогічної освіти загалом; } \\
\text { - недостатнє підвищення кваліфікації } \\
\text { вчителів; } \\
\text { - обмеженість матеріальних та кадрових } \\
\text { ресурсів у сфері освіти. }\end{array}$ & $\begin{array}{l}\text { - Забезпечення з боку державних органів } \\
\text { достатнього фінансового, матеріального } \\
\text { та кадрового забезпечення сфери освіти } \\
\text { загалом, окремих освітніх ініціатив, в } \\
\text { т.ч. інклюзії; } \\
\text { - створення умов для ефективної підго- } \\
\text { товки педагогічного персоналу для по- } \\
\text { треб інклюзивного процесу; } \\
\text { - забезпечення регіональними органами } \\
\text { управління освітою належного рівня } \\
\text { підвищення кваліфікації вчителів }\end{array}$ & \\
\hline $\begin{array}{l}\text { Суспільні бар'єри } \\
\text { - відсутність інформації про переваги } \\
\text { інклюзії для усіх учасників процесу; } \\
\text { - недостатність або непереконливість } \\
\text { інформації; } \\
\text { - необхідні для ефективного впро- } \\
\text { вадження інклюзії зміни виявилися } \\
\text { надто масштабними, а тому їх важко } \\
\text { досягнути за короткий час; } \\
\text { - відсутність уявлень у широкої гро- } \\
\text { мадськості про реальний ефект від за- } \\
\text { провадження інклюзії }\end{array}$ & $\begin{array}{l}\text { - Забезпечення усіх учасників процесу } \\
\text { вичерпною та доступною інформацією } \\
\text { про принципи та переваги інклюзії; } \\
\text { - формування поінформованості про } \\
\text { інклюзивне навчання та позитивного } \\
\text { ставлення до людей з особливими потре- } \\
\text { бами; } \\
\text { - залучення дітей з ООП до активного } \\
\text { суспільного життя та участі у всіх його } \\
\text { аспектах }\end{array}$ & \\
\hline
\end{tabular}




\section{Herald of Lviv University of Trade and Economics. Economic Sciences. № 59, 2020}

Одним із найголовніших завдань запровадження інклюзії в українському соціумі вважаємо підвищення рівня комунікацій та поінформованості суспільства загалом та окремих дотичних цільових аудиторій - перш за все батьків дітей з ООП, представників адміністрації шкіл та педагогів інклюзивних класів, школярів інклюзивних класів, їхніх батьків, а також профільних фахівців (психологів, дефектологів, логопедів, корекційних педагогів тощо). Результатом такої діяльності повинен стати високий рівень лояльності усіх членів суспільства до осіб $з$ інвалідністю та формування інклюзивного середовища.

Висновки i перспективи подальших досліджень у даному напрямі. На основі аналізу статистичних даних щодо кількості осіб з особливими потребами встановлено об'єктивну необхідність запровадження інклюзивної освіти в українському суспільстві. Можна констатувати, що загалом у шкільному середовищі м. Львова та Львівської області сформоване достатньо сприятливе середовище для імплементації інклюзії. В результаті структурного аналізу середовища інклюзивного навчання окреслено основні комунікаційні зв'язки між учасниками процесу інклюзії. Достатнього рівня комунікацій не виявлено у жодному напрямі. Практично повністю відсутні комунікаційні зв'язки між державними органами, громадськістю, батьками нормотипових дітей. Між дітьми з ООП та їхніми батьками й іншими дітьми інклюзивних класів та батьками існує мінімальний рівень комунікацій. Такий самий рівень виявлено між вчителями та батьками нормотипових дітей. Окреслено основні бар'єри комунікацій у середовищі інклюзії на різних рівнях: особистому рівні вчителів, рівні безпосереднього шкільного оточення дітей з ООП, загальношкільному та загальноосвітньому рівнях, а також на суспільному рівні. Більшість комунікативних перешкод зумовлені недостатністю інформації про особливості та переваги запровадження інклюзивного навчання.

Пріоритетним напрямом розвитку інклюзивної освіти в Україні $\epsilon$ адаптація наявних ресурсів до потреб усіх дітей 3 ООП. Це i визначатиме перспективи подальших досліджень.

\section{ЛІТЕРАТУРА}

1. UNESCO: The Salamanca Statement and Framework for Action on Special Needs Education: World Conference on Special Needs Education: Access and Quality, Salamanca, Spain, 7-10 June 1994. Paris: UNESCO, 1994. 50 p.

2. Верховна Рада ухвалила закон "Про внесення змін до закону України "Про освіту" щодо особливостей доступу осіб з особливими освітніми потребами до освітніх послуг" // Укрінформ. 23.05.2017 [Електронний ресурс]. - Режим доступу: https://www.ukrinform.ua/rubric-society/2233310rada-uhvalila-zakon-pro-inkluzivnu-osvitu.html.

3. В Україні низький рівень толерантності щодо дітей-інвалідів - ЮНІСЕФ // Укрінформ. 20.11.2015 [Електронний ресурс]. - Режим доступу: https://www.ukrinform.ua/rubric-society/1917623-vukrajini-nizkiy-riven-tolerantnosti-schodo-diteyinvalidiv-yunisef.html.

4. Драчковська О. Півасистента, або Інклюзія по-українськи / О. Драчковська // Міжнародний громадсько-політичний тижневик Дзеркало тижня. - 8.12.2017. - Вип. №46 [Електронний ресурс]. Режим доступу: https://dt.ua/SOCIUM/pivasistentaabo-inklyuziya-po-ukrayinski-262824_.html.

5. Швадчак Н. Як працює в Україні інклюзивна освіта / Н. Швадчак // LB.ua. - 29.02.2016 [Електронний ресурс]. - Режим доступу: https://lb.ua/society/2016/02/29/328959_yak_pratsyuie _ukraini_inklyuzivna_osvita.html.

6. Беловольченко Г. Про доступність простору й інклюзивну освіту: інтерв'ю 3 експерткою 3 соціальних питань / Г. Беловольченко // Дивись.info. - 23.05.2017 [Електронний ресурс]. Режим доступу: https://dyvys.info/2017/05/23/prodostupnist-prostoru-j-inklyuzyvnu-osvitu-interv-yu-zekspertkoyu-z-sotsialnyh-pytan.

7. Дудар О. Інклюзивна освіта: чи готові загальноосвітні школи прийняти особливих дітей / О. Дудар // Дивись.info. - 9.03.2017 [Електронний pecypc]. - Режим доступу: https://dyvys.info/ 2017/03/09/inklyuzyvna-osvita-chy-gotovizagalnoosvitni-shkoly-pryjnyaty-osoblyvyh-ditej.

8. Особливий підхід: навіщо потрібна інклюзія батькам здорових дітей? // Національна асамблея людей $з$ інвалідністю України. Всеукраїнське громадське об'єднання. - 10.08.2018 [Електронний pecypc]. - Режим доступу: http://naiu.org.ua/ osoblyvyj-pidhid-navishho-potribna-inklyuziyabatkam-zdorovyh-ditej.

9. Національна доповідь про стан і перспективи розвитку освіти в Україні / Нац. акад. пед. наук України ; [редкол.: В. Г. Кремень (голова), В. І. Луговий (заст. голови), А. М. Гуржій (заст. голови), О. Я. Савченко (заст. голови) ; за заг. ред. В. Г. Кременя]. - К. : Педагогічна думка, 2016. 448 с. - Бібліогр.: с. 21. - (До 25-річчя незалежності України).

10. Національна стратегія розвитку освіти в Україні на 2012-2021 роки // Профспілка працівників освіти і науки України. - 01.07.2013 [Електронний ресурс]. - Режим доступу: https://pon.org.ua/ novyny/2446-nacionalna-strategiya-rozvitku-osviti-vukrayini.html.

11. В Україні кількість людей $з$ інвалідністю зросла до 2,6 млн і становить 6\% населення // День day.kyiv.ua. - 27.11.2017 [Електронний ресурс]. Режим доступу: https://day.kyiv.ua/uk/news/281117v-ukrayini-kilkist-lyudey-z-invalidnistyu-zrosla-do-26mln-i-stanovyt-6-naselennya.

12. Кількість людей-інвалідів // Доступ до правди [Електронний ресурс]. - Режим доступу: https://dostup.pravda.com.ua/request/kilkist_liudiei_in validiv.

13. Інклюзивне навчання. Статистичні дані // Міністерство освіти і науки України [Електронний pecypc]. - Режим доступу: https://mon.gov.ua/ua/ statistichni-dani. 
14. Населення // Державна служба статистики України [Електронний ресурс]. - Режим доступу: http://www.ukrstat.gov.ua/.

15. Соціальний захист населення України. Статистичний збірник // Державна служба статистики України. - Київ, 2017. - 122 с.

16. Освіта в Україні (дошкільна, загальна середня, позашкільна). Інформаційно-статистичні матеріали за результатами діяльності у 2016/2017 н. р. // Інститут освітньої аналітики. - Київ, 2017. - 80 с.

17. Pirrie Anne Head George Martians in the Playground: Researching Special Educational Needs Oxford Review of Education / Anne Pirrie. - Vol. 33, No. 1 (Feb., 2007). - Pp. 19-31.

18. Allen K. Eileen, Cowdery Glynnis E. The Exceptional Child. USA: CENGAGE Learning, 2012. $736 \mathrm{p}$.

19. Дітям з особливими потребами. Інклюзивне навчання. Статистичні дані. // Міністерство освіти і науки України [Електронний ресурс]. - Режим доступу: https://mon.gov.ua/ua/statistichni-dani.

\section{REFERENCES}

1. The Salamanca Statement and Framework for Action on Special Needs Education: World Conference on Special Needs Education (1994), UNESCO : Access and Quality, Salamanca, Spain, 7-10 June 1994, UNESCO, Paris, $50 \mathrm{p}$.

2. Verkhovna Rada ukhvalyla zakon "Pro vnesennia zmin do zakonu Ukrainy "Pro osvitu" schodo osoblyvostej dostupu osib z osoblyvymy osvitnimy potrebamy do osvitnikh posluh" (2017), available at : https://www.ukrinform.ua/rubricsociety/2233310-rada-uhvalila-zakon-pro-inkluzivnuosvitu.html.

3. V Ukraini nyz'kyj riven' tolerantnosti schodo ditej-invalidiv (2015), YuNISEF, available at : https://www.ukrinform.ua/rubric-society/1917623-vukrajini-nizkiy-riven-tolerantnosti-schodo-diteyinvalidiv-yunisef.html.

4. Drachkovs'ka O. (2017), Pivasystenta, abo Inkliuziia po-ukrains'ky, Mizhnarodnyj hromads'kopolitychnyj tyzhnevyk, Dzerkalo tyzhnia, available at : https://dt.ua/SOCIUM/pivasistenta-abo-inklyuziya-poukrayinski-262824_html.

5. Shvadchak N. (2016), Yak pratsiuie v Ukraini inkliuzyvna osvita, LB.ua. 29.02.2016, available at: https://lb.ua/society/2016/02/2 9/328959_yak_pratsyuie_ ukraini_inklyuzivna_osvita.html.

6. Belovol'chenko H. (2017), Pro dostupnist' prostoru j inkliuzyvnu osvitu: interv'iu z ekspertkoiu z sotsial'nykh pytan', available at : https://dyvys.info/2017/05/23/pro-dostupnist-prostoruj-inklyuzyvnu-osvitu-interv-yu-z-ekspertkoyu-zsotsialnyh-pytan.
7. Dudar O. (2017), Inkliuzyvna osvita: chy hotovi zahal'noosvitni shkoly pryjniaty osoblyvykh ditej, Dyvys'.info, available at : https://dyvys.info/2017/03/09/inklyuzyvna-osvita-chygotovi-zagalnoosvitni-shkoly-pryjnyaty-osoblyvyhditej.

8. Osoblyvyj pidkhid: navischo potribna inkliuziia bat'kam zdorovykh ditej? (2018), Natsional'na asambleia liudej $\mathrm{z}$ invalidnistiu Ukrainy. Vseukrains'ke hromads'ke ob'iednannia, available at : http://naiu.org.ua/osoblyvyj-pidhid-navishho-potribnainklyuziya-batkam-zdorovyh-ditej.

9. Natsional'na dopovid' pro stan i perspektyvy rozvytku osvity v Ukraini (2016), Pedahohichna dumka, Kyiv, 448 p.

10. Natsional'na stratehiia rozvytku osvity v Ukraini na 2012-2021 roky (2013), available at : https://pon.org.ua/novyny/2446-nacionalna-strategiyarozvitku-osviti-v-ukrayini.html.

11. V Ukraini kil'kist' liudej $\mathrm{z}$ invalidnistiu zrosla do 2,6 mln i stanovyt' 6\% naselennia (2017), Den' day.kyiv.ua, available

at: https://day.kyiv.ua/uk/news/281117-v-ukrayini-kilkistlyudey-z-invalidnistyu-zrosla-do-26-mln-i-stanovyt-6naselennya.

12. Kil'kist' liudej invalidiv, Dostup do pravdy, available https://dostup.pravda.com.ua/request/kilkist_liudiei_in validiv.

13. Inkliuzyvne navchannia (2018), Statystychni dani, Ministerstvo osvity i nauky, available at : https://mon.gov.ua/ua/statistichni-dani.

14. Naselennia, Derzhavna sluzhba statystyky Ukrainy, available at : http://www.ukrstat.gov.ua/.

15. Sotsial'nyj zakhyst naselennia Ukrainy (2017), Statystychnyj zbirnyk, Derzhavna sluzhba statystyky Ukrainy, Kyiv, 2017, 122 s.

16. Osvita v Ukraini (doshkil'na, zahal'na serednia, pozashkil'na) (2017), Informatsijnostatystychni materialy za rezul'tatamy diial'nosti u 2016/2017 n. r., Instytut osvitn'oi analityky, Kyiv, 2017, $80 \mathrm{~s}$.

17. Pirrie Anne (Feb., 2007), Head George Martians in the Playground: Researching Special Educational Needs Oxford Review of Education, vol. 33, No. 1, pp. 19-31.

18. Allen K. Eileen, Cowdery Glynnis E. (2012), The Exceptional Child. USA, CENGAGE Learning, $736 \mathrm{p}$.

19. Ditiam z osoblyvymy potrebamy. Inkliuzyvne navchannia, Statystychni dani, Ministerstvo osvity i nauky Ukrainy, available at : https://mon.gov.ua/ua/statistichni-dani.

Стаття надійшла до редакиій 07лютого 2020 року 